\title{
Empowering Mothers through Mentoring on 6-60 Months Children's Nutrition Care: An Effort to Prevent Child Malnutrition
}

\author{
Sri Umijati ${ }^{1,2 \star}$, Sri Kardjati ${ }^{1,2}$, Ismudijanto ${ }^{1,2}$, Sunarjo ${ }^{1,2}$
}

${ }^{1}$ Universitas Airlangga, Surabaya, INDONESIA

${ }^{2}$ Dr. Soetomo Hospital, Surabaya, INDONESIA

*Corresponding Author: sri-u@fk.unair.ac.id

Citation: Umijati S, Kardjati S, Ismudijanto, Sunarjo. Empowering Mothers through Mentoring on 6-60 Months Children's Nutrition Care: An Effort to Prevent Child Malnutrition. Electron J Gen Med. 2021;18(6):em324. https://doi.org/10.29333/ejgm/11311

\section{ARTICLE INFO}

Received: 8 Sep. 2021

Accepted: 16 Oct. 2021

\begin{abstract}
The prevalence of malnutrition in Indonesia in the last 20 years remains high. This shows that management through curative aspects is not enough. A new strategy is needed to solve the problem as well as to overcome the risk factors. The root cause of malnutrition in Indonesia is the lack of maternal knowledge and power towards their nutrition status. This study aims to determine the mentoring that To do through a tutorial module on malnutrition risk factors. This expects to empower mothers on caring for 6-60 months old children. This research is a twosample experimental study with controls. Respondents were mothers who had children aged 6-60 months. A total of 39 mothers choose a control group and 38 mothers as a treatment group. The mentoring method was given to the treatment group while providing counseling to the control group: multivariate ANOVA and independent $t$-tests to show maternal empowerment. Mentoring on caregiving was very effective in increasing mothers' abilities to care for their children's nutrition $(p<0.05)$. Hence, the mentoring method could empower mothers to care for their children $(p=0.005)$. It took six months to empower $13.2 \%$ of mothers with a minimum knowledge score of 2.5 and practice of 3.1 times, respectively, much higher than the counseling method. Mothers who are already empowering will be aware of any deviation in their children's nutritional status.
\end{abstract}

Keywords: caregiving, children, mentoring, mother empowerment, risk factors

\section{INTRODUCTION}

In Indonesia, the government is against malnutrition in curative aspects, either through maternal skills in feeding children, or high economy, or infection. The same with the opinion [1], the district is being prominent in the district with malnutrition-related to the mother's nutritional status and maternal independence. Inadequate nutrition is born nutrients were lack of energy, protein, or other micronutrients due to its adverse effects on the problem and function of tissues and clinical results [2]. Curative control cannot be practical to the mother in the environment (including children's frogs), bound to happen [3,4]. In Indonesia, the prevalence of childhood malnutrition was unchanged from 2003 to 2013, about 19\% [5, 6], although slightly decreased in 2018 by $17.7 \%$ [7]. Malnutrition incidence in children under five years old in Surabaya, East Java, Indonesia in 2005 remained high at 28.9\% [8], sustainable development goals (SDGs) in 2025 (22.3\%) [9]. These figures show that the problem has not changed in the past two decades. Malnutrition is one of the primary victims of death in toddlers and one of the most common factors that pose a threat to children's life and health [10]. malnutrition has a mortality rate of about $45 \%$ in children under five, despite concerted efforts in malnutrition [11]. For malnutrition of origin, the factors causing it are still present and diking [12]. New strategies are needed to control malnutrition in children to the root of the problem and at the same time to address risk factors [13]. Factors that influence include maternal knowledge, household socio-economic conditions, and distance [14]. Therefore, the prevention aspect can consider as an alternative approach.

The root cause of malnutrition in Indonesia is the lack of maternal skills to care for their child's nutritional status ( $p=$ 0.02) [8]. The role of mothers is the most crucial factor in alleviating the negative impact of dietary problems through their care. Concerning risk factors related to malnourished children in Indonesia are nutrition and health care, breastfeeding, feeding, and environmental management [15]. Child nutrition care consists of the mother's ability to recognize the signs of malnutrition beforehand and monitor the child's growth. Watching a child's development is essential for a health assessment. Energy intake adjusts to energy needs to achieve normal body weight and height for age [16]. The recommended growth graph for use in evaluating children's growth by the World Health Organization (WHO) is compiled based on National Center for Health Statistics (NCHS) data [17].

The parenting risk approach is a new strategy in addressing the problem of malnourished children. Child health and nutritional care are essential for their survival and growth. Children's development reflects their nutritional status [18-20]. Malnutrition can cause physical problems and decrease the quality of life [21]. Mothers should be sensitive in detecting risk factors in parenting that can lead to child malnutrition. That 
Table 1. Distribution of frequency for respondents' characteristic of treatment and control groups with proportion value of $t$-test

\begin{tabular}{|c|c|c|c|c|c|c|c|}
\hline \multirow{3}{*}{ Characteristic } & \multicolumn{4}{|c|}{ Group } & \multirow{2}{*}{\multicolumn{2}{|c|}{ Total }} & \multirow{3}{*}{$\begin{array}{c}\text { Independent t-test between treatment and control groups } \\
p \text {-value }\end{array}$} \\
\hline & \multicolumn{2}{|c|}{ Treatment } & \multicolumn{2}{|c|}{ Control } & & & \\
\hline & $\mathbf{n}$ & $\%$ & $\mathbf{n}$ & $\%$ & $\mathbf{n}$ & $\%$ & \\
\hline \multicolumn{8}{|c|}{ Age (year) } \\
\hline $15-30$ & 14 & 36.8 & 24 & 63.2 & 38 & 100 & \multirow{2}{*}{0.373} \\
\hline $31-45$ & 24 & 61.5 & 15 & 38.5 & 39 & 100 & \\
\hline \multicolumn{8}{|c|}{ Educational level } \\
\hline Low & 23 & 48.9 & 24 & 51.1 & 47 & 100 & \multirow{2}{*}{0.989} \\
\hline High & 15 & 50 & 15 & 50 & 30 & 100 & \\
\hline \multicolumn{8}{|c|}{ Occupation } \\
\hline Yes & 9 & 42.9 & 12 & 57.1 & 21 & 100 & \multirow{2}{*}{0.492} \\
\hline No & 29 & 51.8 & 27 & 48.2 & 56 & 100 & \\
\hline
\end{tabular}

Notes:

1. Low educational level was described as less than or equal to 9-year formal education.

2. High educational level was described as more than or equal to 10 -year formal education

way, mothers can make plans to control children's nutrition and addressing problems that may arise [19,22]. The importance of meeting the needs of balanced nutrition is to prevent the disease in the future, especially chronic diseases among the disease Focus on child health work [23].

Malnutrition information is a significant challenge for mothers. It encourages women's empowerment to build family and community support to increase knowledge and eliminate misinformation about diet to improve health and nutrition [24]. Do an assignment with mentoring. This includes individual learning through mentoring on parenting risks in the Parenting Skills Training Course Module and natural parenting learning $[22,25]$. Do the teaching well through social media and direct knowledge [26]. Nutrition assistance is currently emphasizing counseling, where role models and partnerships are still needed to solve existing problems rather than on society's potential. Based on the explanation, this study aims to determine that mentoring through a tutorial module based on parenting risk factors can empower mothers in caring for children aged 6-60 months.

\section{MATERIALS AND METHODS}

This was a two-sample experimental study with controls. There were treatment and control groups divided into four subgroups based on respondents' education level and occupation. The story of education impacts the knowledge that someone has [27]. The mentoring method was provided to the treatment group, while the control group received the counseling method.

Both groups received learning material consisting of caregiving risk factors related to child malnutrition. The risk factors were general caregiving, growth monitoring, body weight and height measurement, child's nutrition maintenance, breastfeeding, feeding, recognizing the early signs of illness, and maintaining hygiene as well as environmental sanitation.

Risk factor learning in mentoring was provided through the module tutorial strategy, while in the control group by counseling. The mentoring group was also given caregiving skill training and learning in the field. Skill training materials were done by measuring weight and height, growth monitoring, feeding, and recognizing early signs of illness in the child. Indicators of the success of intervention were caregiving empowerment, which includes increased knowledge, attitudes, and practices of mothers to care for their children.
This study was conducted in three poor sub-districts of Surabaya, East Java, Indonesia. Based on the sample size formula experimental design. The proportion of maternal empowerment from each group before the treatment was $12.9 \%$ (the USAID WVI 2005 Surabaya survey results showed that only $12.9 \%$ of mothers received good care). The expected proportion reached $45 \%$, with a 0.05 and $\beta 0.2$ after the treatment. It was found that 38 mothers in the treatment group and 39 mothers in the control group. The inclusion criteria were non-broken families, poor, urban families, having one physically average child and the mothers as the primary caregiver, having formal education diplomas, and participating in mentoring for six months.

The sampling technique was random cluster sampling. One Public Health Centre (PHC) was selected from each sub-district, then 3 Integrated Health Centre (IHC) were chosen from each $\mathrm{PHC}$. Ten mothers who met the inclusion criteria were selected from each IHC. Furthermore, they were divided into treatment or control groups.

The dependent variable of this study was the empowerment of mothers in child nutrition care, and the independent variable was the mentoring of caregiving. Multivariate ANOVA and independent-two-sample t-tests were used to determine maternal assignment in caregiving their child [28]. Before the intervention, the respondents have explained the treatment. Afterward, respondents were asked to sign an agreement to participate in this study.

\section{RESULTS}

This study collected 39 mothers as a control group and 38 mothers as a treatment group from three poor subdistricts of Surabaya.

Table 1 showed that respondents' age, education level, and occupation do not differ in both groups $(p>0.05)$. Likewise, their ability to care for sick children was not different before treatment, and the data had normal distribution ( $p>0.05$ ).

Descriptively, the difference in the average value of the mentoring group was higher than that of the control group. The result of empowerment is better for the mentoring group. Based on standard deviation values, both groups showed significant variations in learning outcomes. In the mentoring group, significant variations showed the results of the individual teaching applied. Differences in the average value of 
Table 2. Mean difference, standard deviation, and probability value of the T and multivariate

\begin{tabular}{|c|c|c|c|c|c|c|c|}
\hline \multirow{2}{*}{\multicolumn{2}{|c|}{ Mothers' abilities }} & \multicolumn{2}{|c|}{ Knowledge } & \multirow{4}{*}{$\begin{array}{c}\text { Mean difference } \\
9.77\end{array}$} & \multicolumn{2}{|c|}{ Skill } & \multirow{4}{*}{$\begin{array}{c}\text { Mean difference } \\
54,5\end{array}$} \\
\hline & & \multirow{3}{*}{$\begin{array}{c}\text { Treatment } \\
229.59 \\
143.1\end{array}$} & \multirow{3}{*}{$\begin{array}{c}\text { Control } \\
23.5 \\
151.25\end{array}$} & & \multirow{3}{*}{$\begin{array}{c}\text { Treatment } \\
45.8 \\
35.98\end{array}$} & \multirow{2}{*}{$\begin{array}{c}\text { Control } \\
0.84\end{array}$} & \\
\hline \multirow{3}{*}{$\begin{array}{l}\text { Caregiving for children } \\
\text { aged 6-60 month }\end{array}$} & mean & & & & & & \\
\hline & SD & & & & & 28.27 & \\
\hline & Manova test & \multicolumn{2}{|c|}{$p=0.0001$} & \multicolumn{4}{|c|}{$p=0.0001$} \\
\hline \multirow{3}{*}{$\begin{array}{l}\text { Maintaining child's } \\
\text { growth }\end{array}$} & mean & 244.9 & 24.78 & \multirow{2}{*}{9.88} & 59.87 & -11.67 & \multirow{2}{*}{6.1} \\
\hline & SD & 114.7 & 42.95 & & 38.25 & 30.23 & \\
\hline & Manova test & \multicolumn{2}{|c|}{$p=0.0001$} & \multicolumn{4}{|c|}{$p=0.0001$} \\
\hline \multirow{3}{*}{$\begin{array}{l}\text { Measuring body's weight } \\
\text { and height }\end{array}$} & mean & 208.06 & 83.16 & \multirow{2}{*}{2.5} & 275.12 & 48.26 & \multirow{2}{*}{5.7} \\
\hline & SD & 168.43 & 105.06 & & 120.8 & 110.67 & \\
\hline & Manova test & \multicolumn{2}{|c|}{$\mathrm{p}=0.0001$} & \multicolumn{4}{|c|}{$p=0.0001$} \\
\hline \multirow{3}{*}{$\begin{array}{c}\text { Maintaining child's } \\
\text { nutrition }\end{array}$} & mean & 513.89 & 1.8 & \multirow{2}{*}{258.5} & 24.55 & 7.9 & \multirow{2}{*}{3.1} \\
\hline & SD & 188.59 & 162.79 & & 26.19 & 38.05 & \\
\hline & Manova test & \multicolumn{2}{|c|}{$p=0.0001$} & \multicolumn{4}{|c|}{$p=0.001$} \\
\hline \multirow{3}{*}{ Breastfeeding } & Mean & 322.47 & 14.27 & \multirow{2}{*}{22.6} & 24.55 & 7.9 & \multirow{2}{*}{10.8} \\
\hline & SD & 119 & 117.67 & & 26.19 & 38.05 & \\
\hline & Independent t-test & \multicolumn{2}{|c|}{$\mathrm{p}=0.0001$} & \multicolumn{4}{|c|}{$p=0.0001$} \\
\hline Cording & Mean & 928.24 & 39.77 & 202 & 77.65 & 6.4 & 12 \\
\hline reeding & SD & 354.3 & 243.48 & 23.3 & 37.57 & 34.8 & 12.1 \\
\hline & Manova test & $p=0.0$ & & & $\mathrm{p}=0$ & & \\
\hline Maintaining good hygiene & Mean & 1176.8 & 334.55 & & 204.65 & 58.88 & \\
\hline and environmental & SD & 1514.3 & 969.79 & 3.5 & 157.48 & 256.02 & 3.5 \\
\hline sanitation & Independent t-test & $\mathrm{p}=0$. & & & $\mathrm{p}=0$ & & \\
\hline & Mean & 816.66 & 114.54 & & 179.5 & 53.0 & \\
\hline Recognizing early signs of & SD & 301.7 & 302.2 & 7.1 & 105.86 & 176.67 & 3.4 \\
\hline & Independent t-test & $p=0.0$ & & & $p=0$. & & \\
\hline
\end{tabular}

Table 3. Frequency distribution in percent of mothers who have the ability of caregiving based on treatment group

\begin{tabular}{|c|c|c|c|c|c|c|c|c|}
\hline \multirow{3}{*}{ Mothers' abilities } & \multicolumn{4}{|c|}{ Treatment group, $n=38$} & \multicolumn{4}{|c|}{ Control Group, n=39 } \\
\hline & \multicolumn{2}{|c|}{ Pre } & \multicolumn{2}{|c|}{ Post } & \multicolumn{2}{|c|}{ Pre } & \multicolumn{2}{|c|}{ Post } \\
\hline & $\mathbf{n}$ & $(\%)$ & $\mathbf{n}$ & $(\%)$ & $\mathbf{n}$ & $(\%)$ & $\mathbf{n}$ & $(\%)$ \\
\hline Caregiving for child aged 6-60 month & 0 & 0 & 5 & 13.2 & 0 & 0 & 0 & 0 \\
\hline Maintaining child's growth & 0 & 0 & 7 & 18.4 & 0 & 0 & 0 & 0 \\
\hline Measuring body's weight and height & 0 & 0 & 20 & 52.6 & 0 & 0 & 0 & 0 \\
\hline Maintaining child's nutrition & 1 & 2.6 & 25 & 65.8 & 0 & 0 & 1 & 2.6 \\
\hline Breastfeeding & 0 & 0 & 21 & 55.3 & 0 & 0 & 0 & 0 \\
\hline Feeding & 0 & 0 & 25 & 65.8 & 0 & 0 & 1 & 2.6 \\
\hline Maintaining good hygiene and environmental sanitation & 10 & 26.3 & 37 & 97.4 & 5 & 12.8 & 10 & 25.6 \\
\hline Recognizing early signs of a illness or sickness & 0 & 0 & 35 & 92.1 & 0 & 0 & 2 & 5.1 \\
\hline
\end{tabular}

Note: Assessment of mothers' caregiving abilities is calculated at more than $70 \%$

knowledge and practice in the two groups $(p<0.005)$ can be seen in Table 2.

Mentoring using child caregiving module learning effectively increased mothers' caregiving abilities related to their child's nutrition $(p<0.05)$. The slightest difference between the two groups ( 2.5 times) occurred in the mothers' knowledge about measuring the child's weight and height. $52.5 \%$ of mothers had this ability for more than $70 \%$, so it took 11.4 months for all mothers to understand this care properly. In the treatment group, changes in the average value of caregiving practices that were more than 100 (like measuring child weight and height, maintaining their hygiene and sanitation, recognizing signs of a sick child) are shown as results of mothers' training activities. Thus, it can be concluded that behavior change with repeated training showed more tremendous activity changes.

Descriptively Table 3 shows that those who receive mentoring may improve their ability to care for sick children.

A few mothers who managed at the end of the mentoring correctly showed that the care provided was new to the mother. Conversely, more than $50 \%$ of mothers who had the ability at the end of the mentoring showed that caregiving's theme was often done in their daily lives or could be caused by provided training during mentoring.

\section{DISCUSSION}

The tutorial module learning resulted in better empowerment efforts compared to counseling $(p<0.005)$. The module tutorial gave a difference in mean caregiving knowledge at least 2.5 times higher than counseling. In contrast, the average difference in caregiving practices was at least 3.1 times higher. The intermediate parenting practice is higher than the mother's knowledge due to skills training or parenting norms that mothers often carry out. The more senses are used in influencing behavior change, the easier the behavior change occurs.

Mentoring is better than counseling because of the following reasons. Tutorial learning is individualized, while counseling is done together [29]. It presents an explanation that builds actual events that exist as a problem and can explore mothers' experiences as students in similar cases that need to be discussed. Thus, various issues that exist and the potential of each participant can be used by other participants 
as experience to be known as a process that must be done in solving problems. Negative experiences often leave a deep impression on the participants. If the occasion is appropriately discussed, it can lead to a lasting positive outlook. Every mother becomes a rich source of learning, and at the same time, she provides a broad base for learning something new. Factors of the level of intelligence, self-confidence, and controlled feelings must be recognized as individual personal rights. The decisions participants make do not have to be always the same.

The tutorial learning involves all participants in learning activities and giving ideas, not only from the theory presented by the supervisor, thus enabling the optimal development of each individual. They feel valuable and had self-respect in front of their peers, having confidence in themselves. Togetherness in groups does not always have to be the same because it acknowledges one truth without criticism that shows the differences, including the differences in their potential.

Learning with modules aims to make students become themselves, understand life's necessities, and carry out their social role assignments. Empowerment does not dominate class groups much and seeks to find alternatives to develop participants' personalities based on their potential and experience. Tutorials can form intensive communication of existing problems because of the guaranteed closeness of the mother and empowerment, increasing the mother's sensitivity to aspects of life that affect health according to the individual's potential.

Learning is not a self-adjustment imposed by others as counseling but needs to deal with life problems that are always dynamic in line with risk factors for caregiving skills. Learning together by tutorial helps mothers deal with the dynamics of behavior change that will produce long-lasting positive behavior [30,31]. Resilience to this positive behavior is formed based on personal experience adjusted by the awareness of the potential risks with consequences. Furthermore, they simultaneously respond and act according to their potential, leading to new stimuli adapted to other new concepts based on existing experience. Thus, this process continues and develops to form self-improvement efforts. In counseling, forced behavior changes will not last long and cannot follow dynamics.

Learning about a child's weight and height measurements increases mothers' empowerment to monitor a child's growth. Growth indicators are dynamic which can be followed from time to time when the weight deviation occurs. The application of mentoring to the nutrition prevention program can significantly improve the child's nutritional status. Policy in several countries in ASEAN applies the nutritional status of children as an indicator of the progress of the people's welfare, not by the average supply or consumption of energy and protein [30]. Adequate food supply does not guarantee every household member to get adequate food and good nutritional status, so it is necessary to understand that it is very important to reduce malnourished and micronutrient people deficiency [32]. Adequate food supply does not guarantee that every household member gets sufficient food and good nutritional status. Many other factors can interfere with the process of establishing a good nutritional status, including clean water, environmental hygiene, and essential health services.

Likewise, the application of the module to maintain a child's hygiene and sanitation and to recognize the early signs of the sick child in a nutrition improvement program can support a child's nutrition status. Changes in the environment and incidence of a sick child can indicate a dynamic on a child's health and interfere with a child's nutrition status. The success of the nutrition program will be more quickly achieved by improving the environment.

Only $13.2 \%$ of mothers have the caregiving ability after mentoring for six months. Thus, it took at least 46 months to empower all mothers to care for children with a minimum capability of $70 \%$. The empowerment of caregiving must be carried out as early as possible before the mother is pregnant for the first time or when the mother is still a teenager.

Generally, mothers have the initial concept that caring for children is natural; mothers are obliged to keep children alive. Likewise, to maintain children's growth, children are miniatures of adults so that in caring for children, mothers care for children as they care for adults. Mothers are not aware of the differences in life needed for children from adult life, including children's growth. The new concept is that mothers must be caregivers according to the child's growth and development.

Changing behavior in something new takes a long time, especially at the stage of contemplation. Mothers begin to realize the importance of caregiving their children and maintaining their growth. With the consideration of mothers' potential, there is a strong sense of ambivalence about changing behavior in a better direction-conversely, behavioral changes in things that have been done as a habit. Mothers have been in the maintenance stage; it does not require a long time to change the behavior.

\section{CONCLUSION}

Mentoring can be used as a new effort in solving child nutrition problems. This effort uses an integrative risk care approach based on community potential, uses indicators of child growth dynamics, and pays attention to the risks of environmental hygiene and children's hygiene. Mothers who had already been empowered will be aware of any deviation in their children's nutritional status. Moreover, the success of the nutrition program will be more quickly achieved by empowering mothers. This study suggests that health policymakers and clinicians prioritize empowering mothers as one of the solutions to prevent child malnutrition.

Author contributions: All authors have sufficiently contributed to the study, and agreed with the results and conclusions.

Funding: This research was supported by the Faculty of Medicine, Universitas Airlangga, and the Government of the Republic of Indonesia c.q. Minister of Education and Culture through Post-Sarar Education Scholarship (BPPS). Thank the Faculty of Medicine of Universitas Airlangga's ethics research committee that gave ethical clearance no. 21/EC/KEPK/FKUA/2009.

Declaration of interest: No conflict of interest is declared by authors.

\section{REFERENCES}

1. Boah M, Azupogo F, Amporfro DA, Abada LA. The epidemiology of undernutrition and its determinants in children under five years in Ghana. Plos One. $2019 \mathrm{Jul}$ 31;14(7):e0219665. https://doi.org/10.1371/journal.pone. 0219665 PMid:31365528 PMCid:PMC6668784 
2. Pulgar IH, Campayo ES, Valero ML. Desnutrición. MedicinePrograma de Formación Médica Continuada Acreditado. 2020 Jun 1;13(14):787-92. https://doi.org/10.1016/ j.med.2020.07.012

3. Lourenco F, Casey BJ. Adjusting behavior to changing environmental demands with development. Neurosci Biobehav Rev. $2013 \quad$ Nov 1;37(9):2233-42. https://doi.org/10.1016/j.neubiorev.2013.03.003 PMid:23518271 PMCid:PMC3751996

4. Wong $\mathrm{B}$, Candolin U. Behavioral responses to changing environments. Behav Ecol. 2015 May 1;26(3):665-73. https://doi.org/10.1093/beheco/aru183

5. RI K. Riset kesehatan dasar [Basic health research]. Republic of Indonesia: Ministry of Health. 2013.

6. Statistics Indonesia. Balita (0-59 Bulan) Menurut Status Gizi, Tahun 1998-2005 (\%) / Nutrition State in Under fivechildren from 1998 to 2005 (\%). 2009.

7. Ministry of Health. Riset Kesehatan Dasar / Basic Health Research 2018

8. Umijati S. Data analysis assessment of basic data on the nutrition situation of under 5 child and mothers in Surabaya in 2005. 2006.

9. Anung. Kesehatan dalam Kerangka Sustainable Development Goals (SDGs) / Health in SDGs Framework. In Rakorpop Kementerian Kesehatan RI 2015. (Issue 97).

10. Mohseni M, Aryankhesal A, Kalantari N. Prevention of malnutrition among children under 5 years old in Iran: A policy analysis. PloS One. 2019 Mar 7;14(3):e0213136. https://doi.org/10.1371/journal.pone.0213136 PMid:30845189 PMCid:PMC6405113

11. Rabaoarisoa CR, Rakotoarison R, Rakotonirainy $\mathrm{NH}$, et al. The importance of public health, poverty reduction programs and women's empowerment in the reduction of child stunting in rural areas of Moramanga and Morondava, Madagascar. PloS One. 2017 Oct 18;12(10):e0186493. https://doi.org/10.1371/journal.pone.0186493 PMid:29045444 PMCid:PMC5646813

12. Mohseni M, Aryankhesal A. Developing a model for prevention of malnutrition among children under 5 years old. BMC Health Ser Res. 2020 Dec;20(1):1-9. https://doi.org/10.1186/s12913-020-05567-x PMid:32758230 PMCid:PMC7405334

13. UNICEF. Improving Child Nutrition: The Achievable Imperative for Global Progress. 2013.

14. Rahman MS, Howlader T, Masud MS, Rahman ML. Association of low-birth weight with malnutrition in children under five years in Bangladesh: do mother's education, socio-economic status, and birth interval matter?. PloS One. 2016 Jun 29;11(6):e0157814. https://doi.org/10.1371/journal.pone.0157814 PMid:27355682 PMCid:PMC4927179

15. Umijati S, Kardjati S. Under fives nutritional rearing model based on risk factors approach. JBP 2012;14(1):30-9.

16. Turck D, Braegger CP, Colombo C, Declercq D, Morton A, Pancheva R, Robberecht E, Stern M, Strandvik B, Wolfe S, Schneider SM. ESPEN-ESPGHAN-ECFS guidelines on nutrition care for infants, children, and adults with cystic fibrosis. Clin Nutr. 2016 Jun 1;35(3):557-77. https://doi.org/10.1016/j.clnu.2016.03.004 PMid:27068495
17. Abedzadeh Zavareh MS, Hasani M, Darabi M, Mirzaei A, Khorshidi A, Saeidi A, Momeni K, Jalilian M. Growth indicators and nutritional supplement evaluation in 6-12 months year old children's: A perspective From Ilam. Electron J Gen Med. 2018 May 1;15(3):em17. https://doi.org/10.29333/ejgm/85494

18. Elder JP, Pequegnat W, Ahmed S, Bachman G, Bullock M, Carlo WA, Chandra-Mouli V, Fox NA, Harkness S, Huebner G, Lombardi J. Caregiver behavior change for child survival and development in low-and middle-income countries: an examination of the evidence. J Health Comm. 2014 May 6;19(sup1):25-66. https://doi.org/10.1080/10810730.2014. 940477 PMid:25207447 PMCid:PMC4263266

19. UNICEF \& WHO. Nurturing Care for Early Childhood Development: A Global Framework for Action and Results. 2018. (Issue May).

20. WHO. Nutrition Landacape Information System Country Profile Indicators: Interpretation Guide. Department of Nutrition for Health and Development World Health Organization 20 Avenue Appia 1211 Geneva 27 Switzerland. In Nutrition Landacape Information System. 2010. https://doi.org/10.1159/000362780.Interpretation

21. Mejia CR, Sulca PA, Hernani-Salazar L, Ricaldi-Asto L, Rojas MA, Hernández-Arriaga G, Tovani-Palone MR, BuesoPineda L. Association of nutritional status and anemia with multi-micronutrient supplementation in young children in Peru. Electron J Gen Med. 2019 Sep 1;16(5):em163. https://doi.org/10.29333/ejgm/114662

22. Laverack G. Public health: power, empowerment and professional practice. Macmillan Int Higher Edu; 2019.

23. Turck D, Braegger CP, Colombo C, Declercq D, Morton A, Pancheva R, Robberecht E, Stern M, Strandvik B, Wolfe S, Schneider SM. ESPEN-ESPGHAN-ECFS guidelines on nutrition care for infants, children, and adults with cystic fibrosis. Clin Nut. 2016 Jun 1;35(3):557-77. https://doi.org/10.1016/j.clnu.2016.03.004 PMid:27068495

24. Bhanbhro S, Kamal T, Diyo RW, Lipoeto NI, Soltani H. Factors affecting maternal nutrition and health: $A$ qualitative study in a matrilineal community in Indonesia. Plos One. 2020 Jun 16;15(6):e0234545. https://doi.org/10.1371/journal.pone.0234545 PMid:32544180 PMCid:PMC7297355

25. Okafor M, Sarpong DF, Ferguson A, Satcher D. Improving health outcomes of children through effective parenting: model and methods. Int J Env Res Pub Health. 2014 Jan;11(1):296-311. https://doi.org/10.3390/ijerph110100 296 PMid:24366048 PMCid:PMC3924445

26. Indarto MR, Sunardi J, Retnowati ND, Sawitri S. Increasing Understanding of General Knowledge of Plastics with Video-based Learning. Universal J Edu Res. 2020;8(11B): 5913-7. https://doi.org/10.13189/ujer.2020.082225

27. Bin Nordin MN, Mustafa MZ, Razzaq AR. Regression between Headmaster Leadership, Task Load and Job Satisfaction of Special Education Integration Program Teacher. Universal J Edu Res. 2020;8(4):1356-62. https://doi.org/10.13189/ujer.2020.080428

28. O'Brien RG, Kaiser MK. MANOVA method for analyzing repeated measures designs: an extensive primer. Psychol Bull. 1985 Mar;97(2):316. https://doi.org/10.1037/00332909.97.2.316 PMid:3983301

29. Notoatmodjo S. (2012). Health Promotion and Behaviour. PT. Rineka Cipta. 
30. Center for Health Leadership and Practice. Mentoring Guide: A Guide for Mentors. In the Center for Health Leadership \& Practice, 2003. Public Health Institute.

31. Woolf SH, Aron L. Panel on Understanding Cross-National Health Differences Among High-Income Countries. Committee on Population. 2013.
32. Beal T, Massiot E, Arsenault JE, Smith MR, Hijmans RJ. Global trends in dietary micronutrient supplies and estimated prevalence of inadequate intakes. PloS One. 2017 Apr 11;12(4):e0175554. https://doi.org/10.1371/ journal.pone.0175554 PMid:28399168 PMCid:PMC5388500 